\title{
Developing Learning Materials in Addition and Subtraction of Fractions with Realistic Mathematics Approach for Students Grade 4
}

\author{
Ari Wijayanti \\ SDN Rejosari, Purworejo, Central Java, Indonesia \\ wijayanti.nisa@gmail.com
}

\begin{abstract}
This study aims to describe the development process of learning materials that consists of lesson plan, student activity sheet, and fraction card. The study focuses on teaching addition and subtraction of fractions through realistic mathematics education. The development process used the Four-D model which consists of four steps: define, design, develop, and disseminate. In the first step (define), the teacher established the terms of learning by determining fundamental problem, analyzing students, and specifying instructional objectives. In the second step (design), the prototype of learning materials was constructed as a test standard, choosing the proper media and selecting the format. On the third step (develop), the learning materials were validated by the experts and then revised. Once the learning materials were ready they were tested in classroom. The teacher then collected data to measure the quality of the learning materials. The last step, dissemination, was the implementation of learning materials on a broad scale. From this step, the teacher collected data to measure the effectiveness of the learning. This study generated good learning materials and supported students Grade 4 to learn about addition and subtraction of fractions. While the results are providing some promising directions, a much larger study would be needed to determine if the results are due to the approach or due to the teachers' enthusiasm or what is known as the Hawthorne Effect.
\end{abstract}

Keywords: development research, fractions, learning materials, realistic mathematics approach, primary school mathematics

\section{Introduction}

Fractions are one of the difficult topics in primary school and these difficulties are also experienced by a teacher at SDN Rejosari who acts as the researcher in this study. In fact, while teaching addition and subtraction of fractions with different denominators a teacher usually asks his/her students to equate the denominators of both fractions directly. This did not motivate the students to find the concept by themselves. It is claimed that this condition was caused by the poor quality of learning materials and so the lesson was less meaningful for the students. Because of this reason, the researcher was challenged to develop learning materials that could help teachers in presenting the topic of addition and subtraction of fractions. They were designed based on realistic mathematic approach with fraction cards and were expected to help students to learn significantly through the process of reinvention (rediscovery).

\section{Literature Review}

Teaching mathematics in a diverse classroom is very challenging, it requires not only skills but also mastery of mathematical concepts. Unfortunately, students' competence in mathematics is only measured by a test even though mathematics is able to support students to solve problems in their daily life. Frei (2008) stated that if the teacher only emphasizes the 
skills and training of mathematics concepts, they have hurt the students. Instead, they should help the student to apply the formula and procedures in real life. Actually, when students learn concepts related to real events they will develop deeper understanding. Application of abstract concepts in real life is an effective learning tool.

A teacher is a facilitator of learning activity, thus effective learning activity is influenced by teachers' ability in planning and implementing the lesson. Therefore, having two tasks as an instructor and class manager, a teacher should be able to create a situation that allows students to learn. As an instructor, he/she is responsible for creating optimal learning activities, while as manager, he/she has responsibility for the effective learning.

\section{Addition and Subtraction of Fractions}

In primary school, the concept of fractions has been taught in the third grade and students Grade 4 begin to learn about addition and subtraction of fractions. Heruman (2007) found that the prerequisites of learning addition and subtraction of fractions are the concept of fractions value, equivalent fractions, as well as the addition and subtraction of whole numbers. Students' mastery of equivalent fractions is needed in the addition and subtraction of fractions with the uncommon (different) denominator. To build their understanding, Reys et al. (2004) suggest that learning about addition and subtraction of fractions should start with problems involving the separation and merger. In addition, the model can also be used in the form of images, not just a symbolic sentence like $2 / 3+1 / 4$.

Problems and models in the form of pictures can also help students understand that the addition and subtraction of fractions can be completed as addition and subtraction using whole numbers. Therefore, they can develop the idea of a reasonable answer. Besides, they will understand why the same denominator is required when adding fractions with uncommon denominators. Furthermore, the things that students know about addition and subtraction of whole numbers can be used to explain the concept of addition and subtraction of fractions. If they have the capability to calculate fractional parts (e.g. $3 / 7+2 / 7$ is $5 / 7$ ) and compare two fractions using an image model, they will find their own way to solve the problem.

\section{Realistic Mathematic Approach}

The realistic mathematic approach is taken from the realistic mathematics education (RME) concept by Freudenthal. Accordingly, this theory emphasizes the richness of thematic context, the integration of mathematics with other issues and reality, individual difference in the learning process, and the importance of working together in heterogeneous group (Treffers, 1991). RME integrates ideas about mathematics, how student learn mathematics, and how mathematics should be taught. 
The realistic mathematic approach, according to Gravemeijer (1994), has three principles: (1) reinvention and progressive mathematizing, (2) didactical phenomenology, and (3) self-developed models.

According to the principle of reinvention, students have the opportunity to experience a process similar to the process in which the mathematic is found. The principle of the invention can be inspired through informal solution procedures. In this case, mathematics creates an opportunity for reinvention. In general, contextual issues are needed for any problem solving. The principle of rediscovery can be inspired by informal procedures, while the progressive mathematical process uses mathematical concepts. De Lange (1996) described the discovery process should be promoted through the exploration of a wide range of real world problems so that mathematic should be close to the students and relevant to their daily life.

The principle of didactic phenomenology emphasizes the importance of educational contextual issues. The didactic phenomenon is finding a contextual situation and approaching the problem in a particular situation. The next step in the process is generalizing in order to achieve a contextual problem solving procedure that can be used as a basis for vertical mathematics. In other words, the contextual problems are expected to guide students in the process of developing their mathematics knowledge.

The last principle is self-developed models. It has a function to bridge the informal and formal knowledge of mathematics. Students get informal knowledge from their real life experiences before they learn the formal mathematical knowledge.

Gravemeijer (1994) described five characteristics of realistic mathematical approach as follows: the use of context, the use of models, the student contribution, interactivity, and intertwining. In realistic mathematical approach, learning begins with contextual issues or problems in daily life. Through the use of context, a student is involved actively in exploring the problem. The exploration is directed at developing a variety of problem solving strategies. Furthermore, the problem can be expressed in the form of mathematical models. Modelling is done to simplify the problem solving or understanding of the concept. The development of a model is used as a bridge between informal and formal situations while a great contribution in the learning process is expected to come from students. Contributions may be a variety of answers or opinions. With production and construction, students are encouraged to reflect on the important parts of their learning process.

Learning process becomes meaningful through the interaction among students and between student and teacher. Students' interactions occur through class discussions or discussions in small groups which allows them to exchange ideas and arguments about the results of their work. Moreover, the interaction between student and teacher could involve an 
explanation, justification, approval, or reflection. It will help student gets a formal mathematical concept from an informal one.

Actually, the concepts in mathematics have relevance because they are not introduced separately. The discussion of a topic usually includes several interrelated concepts. These linkages should be explored in order to introduce and build the understanding of some concepts at the same time.

To start the learning process through realistic mathematic approach, a teacher should provide contextual issues in accordance with the subject matter. Then, students are required to understand the contextual issues. If there are things that have not been understood by the students then the teacher explains or gives directions. Furthermore, the student individually solves problems on worksheets by their own way. While the students solve problems, the teacher observes and controls the activities of the students as well as gives them a chance to compare and discuss the answers to the problem in groups followed by a whole class discussion. After reaching agreement on the best strategies through classroom discussions, the teacher guides the students to make conclusions in order to obtain a formulation of concepts, principles, or procedures.

\section{Learning Materials}

Learning materials are learning resources used in the learning process. According to Ibrahim (2003), learning materials are needed by teacher to manage learning process and they include syllabus, lesson plan, student activity sheet, evaluation instrument or test, instructional media, and book. Learning materials developed in this study include lesson plan, student activity sheet, and fraction media.

\section{Lesson Plan}

Lesson plan is a learning activity plan for one or more meetings. It is developed based on syllabus to guide students' learning activities to achieve basic competency. There are thirteen components of a lesson plan based on the regulation of the Ministry of Education and Culture of Republic of Indonesia (2013) namely: (1) school identity, (2) subject identity, (3) class, (4) subject matter, (5) time allocation, (6) learning objectives, (7) basic competencies and indicators, (8) teaching materials, (9) learning methods, (10) instructional media, (11) learning resources, (12) learning steps, and (13) learning assessment.

\section{Student Activity Sheet}

Student activity sheet is a task that must be done by the student (Majid, 2008). The sheet is typically in the form of instructions and steps to complete a task. Ordinarily, student activity sheet contains a set of basic activities that must be performed by students to enhance 
understanding of the indicators. In the development of these materials, student activity sheet contains contextual problem solving activities such as fraction card to find the solution or other possible strategies.

\section{Test}

A test aims at measuring the standards that have been achieved by students (Purwanto, 2009). Therefore, a test must meet two requirements namely validity and reliability. Purwanto (2009) claims that a test is considered valid if it measures what it is supposed to measure. There are two types of validity namely content validity and construct validity. Content validity examines contents to ascertain whether the test item measures precisely the situation to be measured, while construct validity tests suitability of the construction items and how well they are written according to the criteria. On the other hand, reliability refers to consistency of scores achieved by the same people when they are retested with the same test on different occasions or under different test conditions.

\section{Instructional Media}

Educational practitioners recognize that instructional media is helpful for class activity especially for the improvement of student achievement. However, teachers often use lecturing method which is still quite popular. Instructional media can deliver messages in a planned manner to create a conducive learning environment in which the recipient can make the learning process effective and efficient (Munadi, 2012). It is in line with the definition given by the Association of Education and Communication Technology (AECT) that instructional media is all forms of media used to distribute messages and/or information. Instructional media has several uses, and in general it is directed towards achievement of the learning objectives. Sadiman, et al. (2014) describes four uses of media: (1) to clarify the presentation of the messages, (2) to overcome the limitations of space, time, and sense of power, (3) to overcome the passivity of learners, and (4) to overcome the teachers' difficulties in facing students' different characteristics.

\section{Fraction Card}

Fraction card is a media card made of colored paper. A set of fraction cards consist of three cards, two cards symbolize particular fractions and one card symbolizes unit.

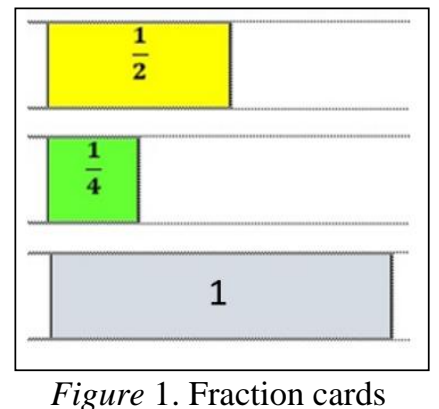




\section{Addition and Subtraction of Fractions Using Fraction Card}

Figure 2 shows the addition of $1 / 4$ and $1 / 2$. The red part is the sum of the two fractions. Students make a shading part of the card which is the sum of the fractions. In addition, they are asked to write a form of the addition of fractions using formal notation. The difference of fractions is determined by putting a card used for subtracting fractions over the other fraction cards. Part of the card which is uncovered represents the difference between the two fractions and is the result of subtraction of the fractions.

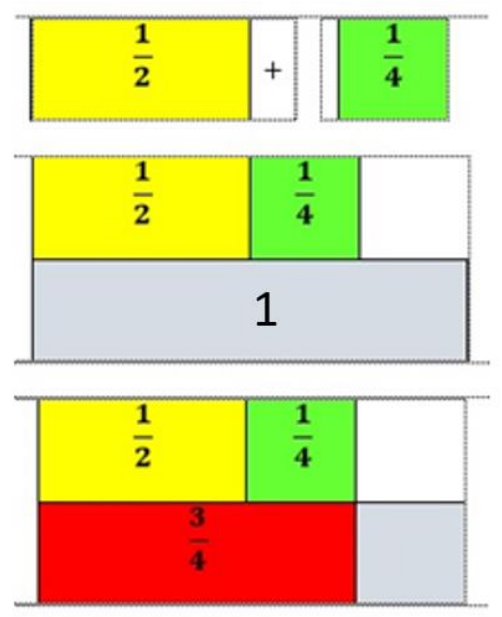

Figure 2. Addition of fractions using fraction cards

The figure shows the subtraction of $1 / 2$ to $1 / 4$. The red part is the result of subtraction. Students shade part on the unit card as the result of subtraction on fractions. Then, they are asked to write a form of subtraction of fraction using a formal notation.

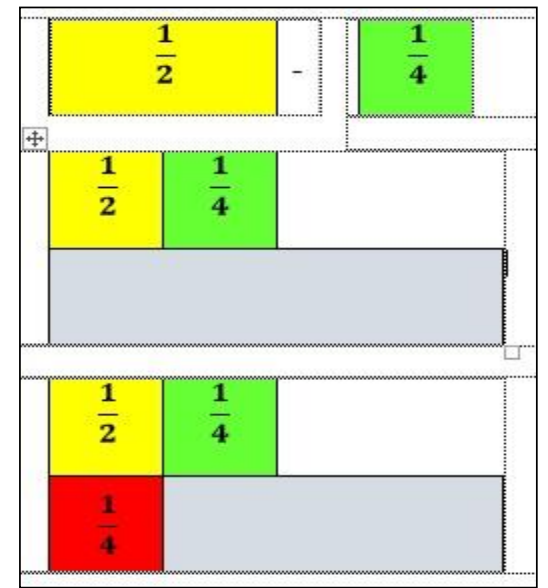

Figure 3. Subtraction of fractions using fraction cards

\section{Development of Learning Materials}

The development model used in this study is the Four-D models by Thiagarajan, Semmel, and Semmel (1974) which consists of four steps: define, design, develop, and disseminate. 


\section{Define}

The purpose of 'define' step is to establish the terms of learning. At this early step, the analysis is done to determine the learning objectives and limitations of the material. Accordingly, this consists of five processes of analysis namely: front-end analysis, learner analysis, task analysis, concept analysis, and specifying instructional objectives. This step is used to determine the fundamental problem faced by the teachers.

Front-end analysis requires consideration of various alternative learning development devices, while learner analysis is performed to examine students with the identification of students' characteristics in accordance with the design and the development of learning. Task analysis aims to identify the skills required and to organize them into a subskill's framework. Concept analysis is done through the identification of main concepts, organizing hierarchically and detailing concepts that are relevant based on their properties. The last process, specifying instructional objectives, is to determine or formulate learning goals.

\section{Design}

The 'design' step aims to create prototype learning materials and consists of four parts, they are preparation of standard reference test, media selection, format selection, and initial design. The preparation of the standard reference test (criterion-construction tests) is a link between 'define' and 'design' stages. It converts the standard reference test objectives into specific outline learning materials. In addition, the media selection step is carried out to determine the right media with the presentation of the subject matter, while the format selection is tailored to the factors outlined in the learning objectives. The format is chosen for the content design, the strategy selection, and the learning resources. The initial design of learning materials is to present learning using the right media and the proper sequence.

\section{Develop}

The purpose 'develop' step is to produce learning materials that are revised based on the input from the experts. This step covers expert appraisal and developmental testing. Validation by the experts is intended to obtain suggestions for improvements. Based on these suggestions, the learning materials are repaired to generate a better result. In the developmental testing, the materials are tested to get responses, reactions, suggestions, and comments from students, teachers, and observers. The test result is revised again based on the feedback from various parties to produce better materials.

\section{Disseminate}

This step is the trial of the developed materials on a broad scale which aims to test the effectiveness of the development results. 


\section{Learning Effectiveness}

The effectiveness of learning is characterized by student's achievement towards learning objectives (Kemp, Morrison, \& Ross, 1994). The effectiveness can be measured by the test results, the project assessment, and the observations of the behavior of the students during the learning process. Pribadi (2011) states that effective learning is the learning that is able to enable students to achieve learning objectives or competencies expected.

Slavin (2005) describes the effectiveness of learning by using the quality, appropriateness, incentive, time (QAIT) model. Each element of the model can be described as follows. The quality of instruction includes the presentation of information or skills that can help students to learn the material which is strongly influenced by curriculum quality. The appropriate levels of instruction includes the suitability of the students learning capacity which refers to the extent to which the teachers ensure that students are ready to learn new lessons (have the necessary skills and knowledge to learn). In other words, the level of learning is appropriate when it is not too difficult or too easy for them. Incentive is where the teachers ensure that students are motivated to work on learning tasks and learn the material presented. Time is the element that determines whether students are given enough time to learn the material.

\section{Methodology}

This is a developmental research and was conducted in the second semester of the school years 2015 and 2016 by using an experimental class and an implementation class. The experimental class was students Grade 4 of SDN Rejosari which consisted of 19 students, while the implementation class was students Grade 4 of SDN Kroyokulon with 17 students.

The researcher used a number of instruments to collect the data. They were validation sheets, student observation sheets, teacher observation sheets, student questionnaire responses to the learning materials, and achievement test. The data was analyzed by qualitative and quantitative description.

\section{Results}

The learning materials of addition and subtraction of fractions with realistic mathematical approach met the criteria of good learning materials.

Table 1.

Quality of Learning Materials

\begin{tabular}{|l|l|l|}
\hline Criteria & Description & Category \\
\hline Validation results & Expert appraisal was at a score of 4. & Valid \\
\hline $\begin{array}{l}\text { Observation results of } \\
\text { teacher's ability }\end{array}$ & Teacher's ability was scored greater than 3. & Good \\
\hline
\end{tabular}




\begin{tabular}{|l|l|l|}
\hline Criteria & Description & Category \\
\hline Students' activities & $\begin{array}{l}\text { Students' activities met the criteria of ideal time with a } \\
\text { tolerance of 10\%. }\end{array}$ & Effective \\
\hline Students' test results & $\begin{array}{l}\text { A total of 79\% of the students' test results reached the } \\
\text { standard. }\end{array}$ & Complete \\
\hline Test & $\begin{array}{l}\text { Test validity was more than } 0.40 . \\
\text { Test reliability was more than } 0.40 .\end{array}$ & $\begin{array}{l}\text { Valid, } \\
\text { reliable }\end{array}$ \\
\hline $\begin{array}{l}\text { Students' response to the } \\
\text { learning materials }\end{array}$ & $\begin{array}{l}\text { More than 75\% students was happy during the learning } \\
\text { process. They also thought the learning materials were new } \\
\text { and clear. }\end{array}$ & Positive \\
\hline
\end{tabular}

Realistic mathematics approach to teach addition and subtraction of fractions is effective for students Grade 4 with the following criteria.

Table 2.

Effectiveness of Learning Materials

\begin{tabular}{|l|l|l|}
\hline Criteria & Description & Category \\
\hline Students' test results & $82 \%$ of student learning outcomes reached the standard. & Complete \\
\hline $\begin{array}{l}\text { Observation results } \\
\text { of teachers' ability }\end{array}$ & Teacher's ability was greater than 3. & Good \\
\hline Students' activities & $\begin{array}{l}\text { Students' activities met the criteria of ideal time with a tolerance } \\
\text { of 10\%. }\end{array}$ & Effective \\
\hline $\begin{array}{l}\text { Students' response to } \\
\text { the learning materials }\end{array}$ & $\begin{array}{l}\text { More than 75\% students was happy during the learning process. } \\
\text { They also thought the learning materials were new and clear. }\end{array}$ & Positive \\
\hline
\end{tabular}

\section{Conclusion}

The process of developing learning materials through realistic mathematics approach follows the systematic Four-D model with four steps: define, design, develop, and disseminate. The learning materials met the criteria of being valid, practical, and effective. The validity was shown by the results of expert appraisal with the score of 4 . The practicality demonstrated by teacher's ability to manage the learning had score 3 . The effectiveness shown by students' activity reached $79 \%$.

The realistic mathematics approach with fractions card was effective in teaching addition and subtraction of fractions for students Grade 4. The effectiveness indicators of the study were the classical mastery with the percentage of $82 \%$, it means students' activity met the effective criteria and their response towards the learning materials was positive.

Due to the limitations of the sample and that there was no evidence that the experimental and the implementation class was similar, the researcher is unable to claim that the results are applicable to other students Grade 4. However, the study may suggest to other teachers a way to develop learning materials through realistic mathematical approach as an alternative in teaching addition and subtraction of fractions. Moreover, other researchers could conduct their own study as a follow-up to enhance the existing weaknesses in order to obtain more accurate research results. 


\section{References}

De Lange, J. (1996). Using and applying mathematics in education. In A.J. Bishop, et al.

(Eds.), International handbook of mathematics education (pp. 49-97). Netherlands: Kluwer.

Frei, S. (2008). Teaching mathematics today. Huntington Beach: Shell Education.

Gravemeijer, K. (1994). Developing realistic mathematics education. Utrecht: CD- B Press.

Heruman. (2013). Model pembelajaran matematika di sekolah dasar. Bandung: PT Remaja Rosdakarya

Ibrahim, M. (2003). Pembelajaran kooperatif. Surabaya: Unesa University Press.

Kemp, J.E., Morisson, G.R., \& Ross, S.M. (1994). Designing effective instruction. USA: Macmillan College Publishing Company.

Majid, A. (2008). Perencanaan pembelajaran. Bandung: PT Remaja Rosdakarya.

Munadi, Y. (2012). Media pembelajaran sebuah pendekatan baru. Jakarta: Gaung Persada.

Pribadi, B. A. (2011). Model desain sistem pembelajaran. Jakarta: Dian Rakyat.

Purwanto. (2009). Evaluasi hasil belajar. Yogyakarta: Pustaka Pelajar.

Reys, R., Lindquist, M., Lambdin, D.V., Suydam, M., \& Smith. N.L. (2004). Helping children learn mathematics. USA: Jhon Wiley \& Sons, Inc.

Sadiman, A.S., Rahardjo, R., Haryono, A., \& Harjito. (2014). Media pendidikan, pengertian, pengembangan, dan pemanfaatannya. Jakarta: PT Raja Grafindo Persada.

Slavin, R. E. (2005). Educational psychology, theory and practice. USA: Pearson Education.

Thiagarajan, S., D.S. Semmel, \& M.I. Semmel. (1974). Instructional development for training teachers of exceptional children, a sourcebook. Bloomington: Indiana University.

Treffers, A. (1991). Realistic mathematics education in the Netherlands. In L. Streefland (Eds.), Realistic mathematics education in primary school. Utrecht: Fruedenthal Institute. 